
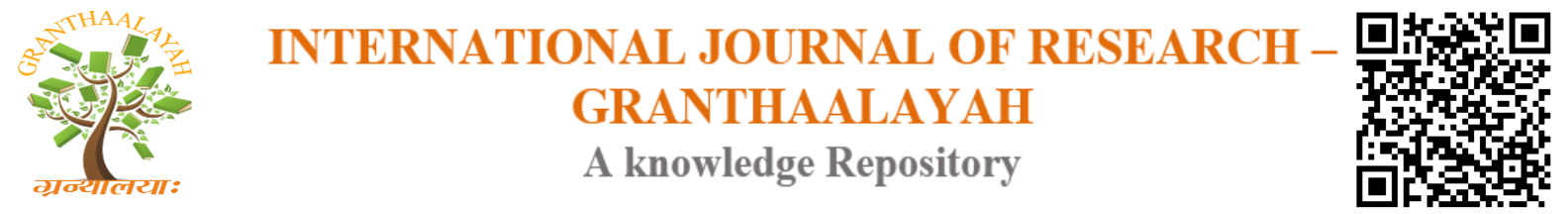

Management

\title{
GENERAL REVIEW OF THE GENETIC AND GEOLOGICAL- ECONOMIC MODELING OF THE MINERAL DEPOSITS OF SERBIA
}

\author{
Radule Tosovic ${ }^{* 1}$ \\ ${ }^{* 1}$ Department of Economic Geology, Faculty of Mining and Geology, Belgrade University, \\ SERBIA
}

DOI: https://doi.org/10.29121/granthaalayah.v4.i6.2016.2634

\section{ABSTRACT}

Changed marketing and economy-ambiental conditions of planning, realization and evaluation of the geological exploration, order quantitative different approach in which are integral implied geology important elements of the deposit of mineral row materials, based the genetic characteristics and marketing necessary question of economy payfull. The conditions and the way of origin the deposit, respectively genetic characteristics, directly across the geological specific of the deposits reflect on the conception and methodology of their geological exploration. On the other side, the changed market conditions, after made community political changes in Serbia, together with the transition problems, in the first plan propound the profitability of the geological work and the results of the geological explorations. In such economy-economic defined conditions of the valorization of mineral resources of Serbia, especially important role has the connected genetic and geologicaleconomic modelling of the deposits of the mineral row materials.

Keywords:

genesis, genetic modelling, geological-economic modelling, deposit, mineral resources, Serbia.

Cite This Article: Radule Tosovic, "GENERAL REVIEW OF THE GENETIC AND GEOLOGICAL-ECONOMIC MODELING OF THE MINERAL DEPOSITS OF SERBIA” International Journal of Research - Granthaalayah, Vol. 4, No. 6 (2016): 38-45.

\section{INTRODUCTION}

Recent transition changes in Serbia, on the road for the market economy, overtake mineral row material complex, too, especially geoindustry and geoadministration. Economy and the jurist settings of this trend are based on the marketing oriented principles, and according that appears the need for the new shapes of geomanagement, than need of the realization the market approved geological exploration and necessarily the global researching geological-economic characteristics of mineral resources of Serbia. Including integral researching the characteristics of the deposit, much bigger importance has the successivety and connects the genetic and geological-economic modelling. The stage in the domain of the problematic the genetic 
modelling of the deposit from Serbia is in more details considered in the series of the published works $[1,2,3,4]$ like the condition of the actually geological-economic evaluation of the deposit $[1,5,6,7,8]$.

Researching metallogenetic characteristics of the mineral resources and viewing their economy importance, in the countries with development economy, is on the high science and professional level. It is realization through the complex modelling of deposit of mineral row materials, with elaborating the prospection criteria's and detail researching the genetic characteristics of the geology environment in which the deposit is. Besides that, we are creating the partial and integral models of the deposit, following the economy conditions and the way of making the marketing valorization the results of the geological exploration in economy global producing geology-mining process.

The complex metallogenetic study of the mineral resources of Serbia are followed by genetic discussing and geological-economic evaluation of the deposit of mineral row materials in the modern conditions, are intensively implemented on the Department of Economic geology, at Faculty of Mining and Geology from the Belgrade University. This scientific and research activity involves more subsegments, outline the subsegment which related on this work, with possibility of the market placement the knowledge what we got through the geological-economic models and market application the results in the different economy domains. The aim of this paper is a brief review of the initial elements relevant to conditions and the way of realization of genetic and geological-economic modelling of mineral deposits in Serbia.

\section{GENETIC MODELLING OF THE DEPOSIT}

Genetic modelling the deposit of mineral row materials according the principles of genetic modelling [1,4], elements and the structure of the genetic models, which are detail elaborated in the series of earlier works $[1,4,9]$ in geological-economic researching of the mineral resources of Serbia is not developed on the satisfying level. The detail genetic models are done for thee little number of geological objects, including Rudnik [1], Bukulja [10] itc. and for some deposits are elaborated the basic elements of geological modelling and developed the structure of genetic models from the author of this work $[9,11,12]$.

The new conditions of the community-economy transformation, problems of the transition and economy orientation on the market economy in Serbia, directly, through the out professional way is related on the conditions and the way of exploration. This, from the practical view, in front of the genetic modelling puts the problem of the strictly market valorization included the economy proved business and projects.

From the scientific-practical essence of genetic modelling of the deposit of mineral row materials follows two specifics which are key for their further route, application and development [4]: (a) scientific character and (b) application and market valorization.

According the nature and the way of the researching genetic modelling has the scientific character, because by the application of the science methods we need to decode of the conditions and the way of origin the deposits and define the elements of the genetic model of the explorated 
deposit. Genetic modelling is very complex and the large problematic which requests collecting, arrangement, systematization, and classification big number of data's and information's, and then the geological-genetic arranging and complex model interpretation in the function of interpretation of the genetic process.

The accepting the market model, like a base of the economy development of Serbia, in recent unfavorable finance conditions ordered necessarily of the maximum including the genetic modelling through the quality geomanagement in the flows of application and market valorization. Earlier approach with the scientific aspect of the genetic modelling, is necessary to full turning the dynamic, marketing, and applicative aspect with thee application marketing manager way of placement the results. Strategy-applicative looking, genetic modelling of the deposits of mineral row materials can further economy exist only by profitable including in adequate pragmatic and finance pay full projects.

\section{GEOLOGICAL-ECONOMIC MODELLING OF THE DEPOSIT}

According the widening and development thee modern science-theory-practical knowledge, geological-economic evaluation of the deposits of mineral row materials lives the transformation and promotion. In the last decade on the course, direction, and the form of its develop the most important reflected the application of the methods of modelling and systematic analysis, respectively system engineering. Like the result of incorporating of the method of modelling origined geological-economic modelling, and by including the modern systematic analytical synthetic procedure is got additional quality-systematic structure.

Geological-economic modelling means the integral way of showing adequate elements and flow of geological-economic evaluation of the deposit of mineral row materials (like analyticalsynthetic process and procedures), through the creation and functional application the different kinds and structures of models $[1,6]$.

The system approach to the developing of the theory bases and practical application of the geological-economic evaluation is necessary for observation all geological-economic problematic. The system organization of data's about the deposit and further developing of the cognition and interpretation this data's has the fundamental meaning.

Geological-economic evaluation of the deposit of mineral row materials, like a complex process and analytical-synthetic procedure, is special system with characteristic groups of factors, like subsystems and with the indicators like elements and they can express through the adequate models, respectively submodels like the constituents of the lower level. By such a system approach, geological-economic mark is showed like the classic relation of the whole-parts, respectively, system-subsystem -elements. By coalition the parameters in the subsystem, and subsystem in the system gives the possibility of fortifying the characteristic wholeness of data's about the evaluated deposit and makes the conditions for the systematic, all in and completely geological-economic researching.

Accepting the system-model approach, and application the methodology of the system analysis for the system of the geological-economic evaluation, it is necessary to define: the parts of the 
system (subsystem), composition of the system, hierarchy of the system like the emergement characteristics.

The geological-economic evaluation of the deposit, like the hierarchy highest level is showed like the model, it consists from subsystems reported through the submodels, which can be [1]: metallogenetic, geological, technical-mining, technology, low-jurisdictional, market, regional, social-political-economic, geoecological etc. The elements important for completing the show of these systems we can group like natural, valuable, and synthetic. Between the big number of indicators of the valuable, natural and synthetic character, which are in the base of the geological-economic mark and its factors, there are the near correlations and functional dependences and it is necessary to group them into the particular subsystems, respectively submodels, including the wholeness over system of the geological-economic evaluation.

Geological-economic modelling of the deposit of mineral row materials of Serbia with such a system structure and form, is on the start of the road of development, although the basic postulates exists for a long time. Already some elements are important for creation of these models of some special models present in the Elaborates about the reserves included the technical-economy evaluation; such a system model is done for Rudnik, now [1].

In the modern trend of application the project standards from the countries of the develop market economy; especially is important turning back on the prefeasibility and feasibility analysis [13]. Geological-economic model is more widely and global and contents the data's and information's on which base we can isolate the elements for making one or the other analysis. From that aspect, geological-economic evaluation, which was done since now, has the prove for further existing, especially for the improvement through the geological-economic models of mineral row materials of Serbia, with the condition including the new methods of the geology and economy evaluation of the mineral resources.

\section{GENETIC AND GEOLOGICAL-ECONOMIC MODELLING OF THE DEPOSIT}

Information's which we got by genetic modelling the deposit of the mineral row materials, in the changed economy conditions in Serbia must be maximum adapted by the purpose, to satisfy the really needs and be in the function of making profit, respectively to have reported economy dimension. In that sense, economic modelling share the destiny the whole scientific work, which need to be put into the practical role. In the launching marketing oriented economy ambient, on genetic modelling deposits of the mineral row materials are possible application two concepts: (a) pull concept and (b) push concept. Pull concept comes from the concretely genetic problem of the particular deposit to its final solution through the genetic modelling. Push concept signs the theory-scientific researching, followed by the experiments and model analysis, and after that finding the deposit of the mineral row materials for the application information's which we got by genetic modelling through concretely project. The advance in the started science-researching project has the pull concept, which is connected to the choosing particular type etalon geology objects, and then widening the application on the others geology similar deposits of the mineral row materials. 
The necessarily of the more important change of the partial and integral genetic modelling of the deposit of mineral row materials, like the material-spacement-time phenomena's, due from the fact that the most important geological characteristics of the deposit of mineral row materials are the consequence of the process of their forming. The quality genetic modelling because of that is the most quality base for the completely geology defining the deposit of the mineral row materials, and with that more security conditions for mining the deposit and postulate for more profit work in the wholeness.

Mineral resources and defined deposits of the metallic, non-metallic and energy mineral row materials from Serbia are the objects of genetic and geological-economic modelling. From that aspect, much elements are got through the segments of genetic model, reaching: source of the ore elements, mechanism of mobilization and concentration, transportation, disposal, following apparition of the disposal and post ore processes, which are directly applicationed in agreeable submodels of the geological-economic models. It related to the metallogenetic and geological submodel partly on mining, technological, geoecological itc. From that reasons of combination the genetic researching the conditions and the way of origin, which are conditions for knowing the deposit, we put the basis on which we give the overbuilt through the including some segments into the geological-economic model, especially in technical and economy elements. Adding the new data's and information's which related partly on mining, technology and ecology submodel, and totally on regional, social-economy-political, marketing and lowjurisdiction submodel, we got the complete and surrounded scientific-economy picture of the mineral resources or some geological objects in the composite the complex researching of the mineral-row material base of Serbia.

Special attention pays the practical meaning of the combination genetic and geological-economic model of the deposit, because through the other one, depending a phase of researching the deposit, they give the information's which are directly important for the profitability of the exploration, mining, and to the end economy effects geology-mining -technology work. Besides that it is important to include into the treating problematic the big number of the elements of organization, economic, management $[14,15]$, marketing, geoecology, informatics itc. The part of the geological-economic models which in the next period requires especially necessary additional work is the part with economy evaluation in which we must include in the world used methods of the economic evaluation: NPV, IRR, cost-benefit itc.

Genetic and geological-economic model of the deposit is characterized the researching functions which implied: (a) researching genetic/geological-economic model alone; (b) researching the modeled deposit and (c) improvement geological-genetic-economic knowledge about the modeled deposit. This is especially important for the increasing representatively of the model and their qualitative overbuilt, whose end object is more efficiently exploration and more profitability work.

The work on the genetic and geological-economic modelling mineral resources of Serbia, in the part of the activity realized since now, involved collecting particular population of data's because of the viewing the choice of strategy primary mineral row materials and deposits which are from the interest for further economy development of Serbia. The other part involved the studios exploration the knowledge abroad about the genetic and genetic-economy models in the past 
decade, so the newest domains and experiences from abroad for application, for us in the further science-researching work. The analytical phase is running and together with the researching characteristics some of the mineral resources and most important geological objects (deposits and appearances), and following complex synthetic elaborating of the models of chosen etalon deposits according the single mineral resources. Special importance will have following elaboration of the geological-economic models, especially in the part with the geologicaleconomic parameters of evaluation the deposits in the modern transition conditions, according to the market criteria which are in the develop mineral economies.

Starting from the showed elements of the models-system approach in the genetic modelling and geological-economic evaluation the deposit of the mineral row materials, in the next period is necessary more intensive collecting and systematization, classification and arrangement complex additional informations. This is important especially because of the wholes looking at the genetic characteristics and geological-economic information's in the essence important for the whole structuring the models, respectively, defining the models and submodels, which are adequate to the genetic and geological-economic characteristics of the deposits of mineral row materials of Serbia. In the modern geoecology trend, especially in the consideration the correlation of mineral resources and environmental pollution, geological-economic modelling, especially created geoecological submodel of deposit has the special importance [16].

\section{CONCLUSION}

The information's which we got by geological-economic modelling of the deposit of mineral row materials, in the changed economy conditions in Serbia, must be maximal accommodation according the propose to the real needs and to be in the function of making profit.

Mineral resources and defined deposits of the metallic, non-metallic and energy mineral row materials from Serbia are the objects of the genetic and geological-economic modelling. Much elements which we got through the genetic modelling has the directly application in the adequate submodels of the geological-economic models. It is especially related on metallogenetic and geological submodel, partly on mining, technological, geoecological itc. The combination of the genetic researching of the conditions and the way of forming is the basis on which we give the overbuilt through the fitting of some segments in geological-economic model, especially by technical end economy elements. Adding the new data's and information's which related partly on mining, technology and ecology submodel, and total on regional, social-economy-political, marketing and low-jurisdiction submodel, we got the completely and surrounded scienceeconomy picture of the mineral resources and single objects in the composite of complex exploration of the mineral-row material base of Serbia.

The dynamic plan and the program of the development genetic and geological-economic modelling the deposit of mineral row materials of Serbia, besides the necessary keeping the science level, predict the harmonizing with the economy lows of market and possibilities of getting profit through the placement the information's of genetic and geological-economic modelling. Only by science-marketing profitability approach, in the changed economy conditions in Serbia, will be made the base for further proved development genetic and geological- 
economic modelling in the composite economy and susatinable use of the mineral resources of Serbia.

\section{REFERENCES}

[1] Tošović R., Geological-Economic Modelling of the Rudnik Polymetallic Deposit (Serbia), Department of economic geology, Faculty of Mining and Geology, Belgrade University, Spec. ed. No. 8, 226 pp., Belgrade, 2006.

[2] Tošović R., General Specifics of Genetic Modelling of Gem Raw Materials Deposit of Serbia, Proceedings of the 3th International Conference, "Stone 2002", pp. 368-371, Arandjelovac, 2002.

[3] Tošović R., Research and Integral Function of Partial Genetic Model of Mineral Deposits, Proceedings of the 13th Congress of the Geologists of Yugoslavia, vol. IV mineral resources, pp. 455-469, Herceg Novi, 1998.

[4] Tošović R., A brief Overview of the Genetic Modeling of Mineral Deposits in the New Economic Conditions, Proceedings of the IV Scientific conference Underground mining of mineral resources in the new economic conditions, Faculty of Mining and Geology, pp. 221-224, Belgrade, 2001.

[5] Milovanović D., Complex Economic Evaluation of Mineral and Raw Material Base of Yugoslavia as a Function of its Development Strategy, Proceedings MISKO MMIII, Faculty of Mining and Geology, pp. 126-134, Belgrade, 2003.

[6] Tošović R., Geological-Economic Modeling of Mineral Deposits, Proceedings of the 14th Geological Congress Serbia and Montenegro, 8 pp., Novi Sad, 2005.

[7] Tošović R., Strategic Functions of Economic Evaluation with Competitiveness of Mineral Economy, 19th International Scientific Conference, SM2014 Strategic Management and Decision Support System in Strategic Management, Faculty of Economics Subotica, pp. 422-429, Subotica, 2014.

[8] Tošović R., Reserve Economic Evaluation and Industrial Routes for Mineral Economy Development, XIX International Symposium on Project Management, YUPMA 2015, 12 14.06.2015. Beograd, 74-78, Belgrade, 2015.

[9] Tošović R., The Basic Elements of Genetic Modeling Deposits of Brick Raw Crvenka, Proceedings KOMSEKO '98, Faculty of Mining and Geology, pp. 33-36, Kanjiža, 1998.

[10] Jelenković R., Uranium Mineralization of Šumadija: Genetic and Morphostructural Types, Faculty of Mining and Geology, Spec. ed. No. 2, 187 pp., Belgrade, 1991.

[11] Tošović R., The Basic Elements of the Genetic Deposits Modeling Clay Marl Tepe near Novi Pazar,Proceedings KOMSEKO 2000, Faculty of Mining and Geology,, pp. 33-36, Budva, 2000.

[12] Tošović R., The Basic Elements of the Genetic Deposits Modeling Marl Trešnja (Popovac near Paracin), Proceedings of the International Conference "Cement 99", Yugoslav Committee for surface mining, pp. 176-182, Novi Sad - Beočin, 1999.

[13] Tošović R., Milovanović D., Relations Between the Geological-Economic Evaluation of Mineral Deposits and Preafisibility and Feasibility Studies in the Evaluation of Mineral Resources in Serbia, Proceedings counseling IMES'03, pp. 252-260, Arandelovac, 2003.

[14] Tošović R., Milovanović D., Geological-Economic Evaluation of the Function of Geomanagement Activities, Tehnika, Rud.,Geolog.i Metal., LXII, 5, pp. 9-16, Belgrade, 2007. 
[15] Tošović R., Management in Modern Conditions of Serbian Mineral Economy, Proceedings MISKO 10, pp. 411-434, Belgrade, 2010.

[16] Tošović R., Geoecolocical Model in the Constitution of Evaluation of Mineral Deposit, Proceeding of the First Intenational Symposium Ecology, Environment, Energy\&Technology, EEET-XXI/1 2004, pp. 7-10, Belgrade, 2004. 